\title{
Gambaran Pemakaian Antibiotika Setelah Implementasi Pedoman Pemakaian Antibiotika di Bangsal Kenanga RSUD Arifin Achmad Provinsi Riau Periode Juni-Agustus 2016
}

\author{
Dani Rosdiana ${ }^{1 *}$ Mukhyarjon $^{1}$ Dewi Anggraini ${ }^{2}$
}

\begin{abstract}
Implementation of antibiotic guideline as part of "Antibiotic Stewardship Programs (ASPs)", can both optimize the treatment of infections and reduce adverse events associated with antibiotic use, antibiotic resistance and saving hospitals funds. This study describes quantitative and qualitative evaluation and cost of antibiotic use after implementation of antibiotic guideline in Kenanga ward Arifin Achmad General Hospital.This research was a descriptive prospective study. All inpatients given antibiotic in Kenanga ward from June - August 2016 were evaluated. The quantitative antibiotic use was calculated with DDD (daily define dose) meanwhile Gyssens method was used to calculate qualitative of antibiotic use. There were 137 patients fulfilled inclusion criteria. The most antibiotic used were ceftriaxone, ciprofloxacin, levofloxacin, meropenem and cefoperazone. There was increased consumption of quinolone class antibiotics. The highest DDD's antibiotic was ceftriaxone (96.5). Qualitative measurement showed that rational antibiotic (Gyssens category 0) was 46\%, irrational (Gyssens category I - IV) was $35 \%$ and no indication of antibiotic use (Gyssens category V) was 19\%. The total cost of antibiotics in this period were Rp 41,444,766.After antibiotic guideline implementation, we found that the most frequent antibiotic was ceftriaxone and irrational use of antibiotic was still high.
\end{abstract}

Key words: antibiotic guideline, define daily dose, Gyssens method

Antimikroba yang terdiri dari antibiotika, anti jamur, anti virus dan anti protozoa merupakan modalitas dalam penanganan infeksi dimana antibiotika merupakan obat yang paling banyak penggunaannya.Namun berbagai studi menemukan bahwa sekitar 40-62\% antibiotika digunakan secara tidak tepat baikmisuse, under use atau over use. ${ }^{1}$ Hal ini memicu permasalahan baru berupa ancaman global kesehatan berupa resistensi terhadap antibiotika.Selain berdampak pada morbiditas dan mortalitas, resistensi antibiotika ini juga memberikan dampak negatif terhadap beban ekonomi dan sosial. Diperkirakan akan terjadi suatu masa dimana antibiotika sudah tidak dapat lagi bekerja karena resisten dan pasien dengan infeksi tidak dapat ditolong dengan antibiotika.

\footnotetext{
1 KJF Ilmu Penyakit Dalam Fakultas Kedokteran Universitas Riau- RSUD Arifin Achmad Provinsi Riau

2 KJF Mikrobiologi Fakultas Kedokteran Universitas Riau

* Korespondensi:dr.danirosdiana@yahoo.com
}

Resistensi antibiotika dapat terjadi di tingkat rumah sakit maupun pada komunitas.Penyebab munculnya kuman resisten antibiotikasalah satunya akibat penggunaan antibiotika yang tidak bijak dan penerapan kewaspadaan standar (standar precaution) yang tidak benar di fasilitas pelayanan kesehatan. Untuk mengoptimalkan penggunaan antibiotika secara bijak (prudent use of antibiotics) perlu disusun pedoman umum penggunaan antibiotika di sebuah rumah sakit. Pedoman ini disusun berdasarkan pedoman yang dikeluarkan oleh kementerian kesehatan dan disesuaikan dengan laporan pola resistensi di sebuah rumah sakit. Pedoman ini digunakan sebagai acuan dalam penggunaan antibiotika sebagai terapi empiris sebelum keluar hasil biakan kuman dalam penatalaksanaan penyakit infeksi. ${ }^{2,3}$

Hanberger dkk dalam penelitiannya mengenai pengaruh perubahan kebijakan penggunaan antibiotika dan implementasi antibiotic stewardship di beberapa rumah sakit Swedia menyimpulkan 
bahwa pemakaian antibiotika yang tepat, dengan dasar bukti-bukti ilmiah dapat meningkatkan efektivitas penggunaan antibiotik dan menurunkan angka resistensi. ${ }^{4}$ Sebuah penelitian deskriptif kualitatif yang dilakukan oleh negara di Bali mengenai implementasi kebijakan penggunaan antibiotika rasional untuk mencegah resistensi antibiotika, juga menemukan bahwa penerapan pedoman penggunan antibiotika rasional yang tidak berjalan dengan baik, akan menimbulkan permasalahan resistensi yang tinggi di lingkungan rumah sakit dan dapat berdampak kepada peningkatan morbiditas dan mortalitas, lama hari rawat dan meningkatnya biaya perawatan rumah sakit. $^{5}$

Dalam upaya untuk meningkatan mutu penggunaan antibiotika, dilakukan penilaian kuantitas dan kualitas penggunaan antibiotika, yang dapat diukur secara retrospektif dan prospektif melalui data rekam medis dan Rekam Pemberian Antibiotika (RPA). Penilaian ini bertujuan untuk mengetahui jumlah atau konsumsi penggunaan antibiotika di rumah sakit, mengevaluasi kualitas penggunaan antibiotika, dan nantinya menjadi dasar untuk melakukan surveilans penggunaan antibiotika di rumah sakit secara sistematik dan terstandar.Penilaian secara kuantitatif dilakukan dengan menghitung kuantitas penggunaan antibiotika yang dinyatakan sebagai dosis harian ditetapkan dengan Defined Daily Doses (DDD)/100 patient days. Alur penilaian menggunakan kategori Gyssens digunakan untuk menilai pemakaian antibiotika secara kualitatif. Penggunaan antibiotika dinilai dengan melihat rekam medis pemberian antibiotika dan rekam medis pasien dengan mempertimbangkan kesesuaian diagnosis (gejala klinis dan hasil laboratorium), indikasi, regimen dosis, keamanan dan harga. ${ }^{6,7}$

Berild dkk.meneliti penurunan penggunaan dan biaya antibiotika dengan penerapan pedoman penggunaan antibiotika di Rumah Sakit Universitas Aker di Oslo, Norwegia. Pada penelitian ini digunakan suatu pedoman yang digunakan untuk sebagai dasar pemakaian antibiotika untuk terapi dan profilaksis.Dari penelitian ini didapatkan penurunan yang signifikan yaitu sebanyak $11 \%$ penggunaan antibiotika selama dua tahun penelitian dilakukan.Penggunaan antibiotika spektrum luas menurun sebanyak $23 \%$. Penurunan juga terjadi pada biaya penggunaan antibiotika sebesar $27 \%$ pada tahun pertama digunakannya pedoman penggunaan antibiotika, sebesar USD 319.300 serta penurunan sebanyak $32 \%$ pada tahun selanjutnya, sebesar USD 380,000. ${ }^{8}$

Hingga tahun 2015, RSUD Arifin Achmad belum memiliki data mengenai penggunaan antibiotika meliputi kepatuhan dalam mengikuti pedoman penggunaan antibiotika yang telah disesuaikan dengan laporan pola resistensi rumah sakit, sehingga dapat mengakibatkan inefisiensi biaya perawatan pasien terutama untuk pengeluaran antibiotika.Pada bulan Mei 2015 telah terbentuk Tim Pengendalian Resistensi Antibiotika (PPRA) RSUD Arifin Achmad untuk mengevaluasi penggunaan antibiotika.Berdasarkan survei awal, didapatkan hasil dimana pemakaian antibiotika di bangsal Penyakit Dalam cukup tinggi.

Tujuan penelitian ini adalah melakukan penilaian kuantitatif dengan DDD dan kualitatif penggunaan antibiotika dengan alur Gyssens serta menghitung biaya yang dikeluarkan untuk pembelian antibiotika setelah diberlakukan pedoman pemakaian antibiotika di bangsal penyakit dalam RSUD Arifin Achmad Provinsi Riau pada bulan Juni - September 2016.

\section{METODE}

Penelitian ini merupakan penelitian deskriptif prospektif.Setelah disusun buku panduan penggunaan antibiotika secara empiris kemudian dilakukan beberapa pengukuran.Penggunaan antibiotika secara kuantitatif dihitung berdasarkan data dosis harian per bulan (variable define daily dose) dengan mengacu pada klasifikasi Anatomical Therapeutic Chemical (ATC).Analisis dengan alur Gyssens digunakan untuk menilai rasionalisasi penggunaan antibiotika (kualitatif).Jumlah biaya yang dikeluarkan untuk pengadaan antibiotika dihitung dari bulan Juni hingga bulan Agustus 2016. Kriteria inklusi adalah semua pasien yang mendapatkan antibiotika baik secara empiris maupun definitif berdasarkan hasil kultur yang dirawat di Bangsal Kenanga RSUD Arifin Achmad selama kurun waktu penelitian. Terapi empiris adalah terapi antibiotika pada infeksi sebelum diketahui kuman penyebab pasti. Pasien pindahan dari ruang lain tidak diikutkan dalam penelitian ini. 
Begitu juga dengan pasien yang dalam masa perawatan pindah ke ruang lain dimasukkan dalam kriteria eksklusi. Teknik pengambilan sampel adalah secara consecutive sampling.

Rasionalisasi penggunaan antibiotika dengan menganalisa dengan alur Gyssens. Untuk itu dibutuhkan data dasar antara lain: diagnosis utama yaitu ada tidaknya infeksi, darah rutin, fungsi ginjal, fungsi hati dicatat. Selain itu juga dicatat jenis, dosis, interval pemberian, lama pemberian antibiotika, reaksi alergi serta hasil akhir pengobatan, kemudian juga dicatat riwayat kultur, spesimen kultur, hasil kultur. Evaluasi dengan alur Gyssens dilakukan dengan cara menggolongkan setiap antibiotika menjadi 6 kategori, yaitu : Kategori VI (penggunaan tidak tepat karena catatan rekam medik tidak lengkap untuk dievaluasi), kategori $\mathrm{V}$ (penggunaan tidak tepat karena tidak ada indikasi), kategori IVa (ada antibiotika lain yang lebih efektif), kategori IVb (penggunaan tidak tepat karena ada antibiotik lain yang lebih aman), kategori IVc (penggunaan tidak tepat karena ada antibiotik lain yang lebih murah), kategori IVd (penggunaan tidak tepat karena ada antibiotik lain yang spektrumnya lebih spesifik), kategori IIIa (penggunaan tidak tepat karena terlalu lama), kategori IIIb (penggunaan tidak tepat karena terlalu singkat), kategori IIa (penggunaan tidak tepat dosis pemberian), kategori IIb (penggunaan tidak tepat interval pemberian), kategori IIc (penggunaan tidaktepat cara/rute pemberian) dan kategori I penggunaan antibiotik tepat, dan kategori 0 (penggunaan antibiotika secara bijak/tepat).

\section{HASIL}

Didapatkan 137 pasien yang mendapatkan antibiotika di Bangsal Kenanga dari bulan Juni hingga Agustus 2016 dari 410 pasien (33,42\%), dengan jumlah pemakaian antibiotika 160 sampel (1 pasien bisa mendapatkan lebih dari 1 antibiotika)

Tabel 1. Sebaran rasionalisasi antibiotika berdasarkan alur Gyssens

\begin{tabular}{ll}
\hline \multicolumn{1}{c}{ Kategori Gyssens } & $\%$ \\
\hline 0 (rasional) & 46 \\
I - IV (tidak rasional) & 35 \\
V (tidak ada indikasi) & 19 \\
\hline
\end{tabular}

Tabel 2. Sebaran penggunaan antibiotika

\begin{tabular}{lcc}
\hline Antibiotika yang digunakan & Jumlah (n) & $\%$ \\
\hline Betalaktam & & \\
$\quad$ Ampisilin & 1 & $0,63 \%$ \\
$\quad$ Ampisilin sulbactam & 1 & $0,63 \%$ \\
Sefalopsorin & & \\
$\quad$ Sefotaksim & 7 & $4,38 \%$ \\
Seftriakson & 82 & $51,25 \%$ \\
Sefiksim & 1 & $0,63 \%$ \\
Seftazidim & 3 & $1,88 \%$ \\
$\quad$ Sefoperason & 6 & $3,75 \%$ \\
Karbapenem & & \\
$\quad$ Meropenem & 9 & $5,63 \%$ \\
Aminoglikosida & & \\
$\quad$ Gentamisin & 2 & $1,25 \%$ \\
Kuinolon & & \\
$\quad$ Levofloksasin & 19 & $11,88 \%$ \\
$\quad$ Ciprofloksasin & 19 & $11,88 \%$ \\
Metronidazol & 6 & $3,75 \%$ \\
Kotrimoksasol & 3 & $1,88 \%$ \\
Kloramphenicol & 1 & $0,63 \%$ \\
\hline$\quad$ TOTAL & 160 & $100 \%$ \\
\hline
\end{tabular}

Sebaran penggunaan antibiotika dapat dilihat pada Tabel 2. Disini tercatat 5 antibiotika terbanyak yang dipakai adalah: golongan seftriakson, levofloksasin, ciprofloksasin, meropenem dan sefotaksim.

Tabel 3. Distribusi frekuensi DDD per kelas antibiotika

\begin{tabular}{lccc}
\hline \multirow{2}{*}{ Jenis Antibiotika } & \multicolumn{3}{c}{ Define Daily Doses (DDD) } \\
\cline { 2 - 4 } & Juni 2016 & Juli 2016 & Agustus 2016 \\
\hline Seftriakson & 65 & 96,5 & 90,5 \\
Sefotaksim & 0,5 & 8 & 4 \\
Siprofloksasin & 58 & 4 & 48,4 \\
Levofloksasin & 1 & 35 & 75 \\
Sefoperason & 13,5 & 3 & 3,5 \\
Meropenem & 11 & 23 & 9,25 \\
Metronidazole & 9 & 25 & 26 \\
\hline
\end{tabular}

Jumlah pembiayaan untuk antibiotika per bulan dapat dilihat pada gambar dibawah ini:

Total biaya yang dikeluarkan untuk pembelian antibiotika

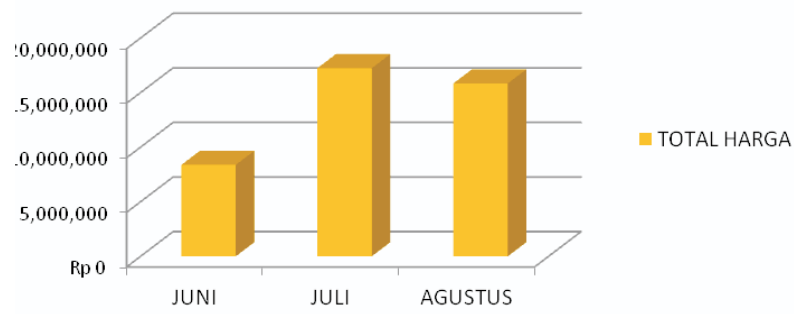

Gambar 1. Grafik total pembiayaan untuk pembelian antibiotika dalam 3 bulan 


\section{PEMBAHASAN}

Penggunaan antibiotika di Bangsal Kenanga masih tinggi yaitu137 pasien dari 410 pasien yang dirawat $(33,41 \%)$. Angka ini bahkan lebih tinggi dari penelitian Irene Yuniar dkk.diIntensive Care Unit (ICU)Rumah Sakit Cipto Mangunkusumo (RSCM)dimana pemakaian antibiotika mencapai 19,3\%. ${ }^{9}$ Namun dari 137 pasien yang mendapatkan antibiotika empiris, hanya 46 pasien $(33,57 \%)$ yang dilakukan kultur. Padahal kultur sangat penting untuk membuktikan keberadaan kuman sekaligus membuat data pola kuman untuk kurun waktu tertentu, disamping itu hasil kultur dapat menentukan keputusan klinisi kapan harus mengganti atau menghentikan antibiotika. Penggunaan antibiotika yang tidak tepat justru berpotensi menimbulkan resistensi antibiotika. Resistensi antibiotika meningkatkan beban ekonomi pada sistem kesehatan, bahkan di Amerika Serikat biaya yang dikeluarkan hampir mencapai 8 juta Dollar US. ${ }^{10}$

Berdasarkan jenis antibiotika, golongan seftriakson merupakan antibiotika yang paling sering dipakai untuk berbagai diagnosis dan terapi empiris.Tingginya pemakaian seftriakson menunjukkan bahwa panduan terapi empiris masih belum dipatuhi, hal ini dengan penelusuran berbagai diagnosis yang tidak sesuai terapi empirisnya dan dapat dilihat pada analisa alur Gyssens yang akan dibahas kemudian. Penelitian oleh Luciana di RS Fatmawati tahun 2010 didapatkan bahwa seftriakson merupakan antibiotika yang paling sering diresepkan yaitu mencapai $34 \% .{ }^{11}$

Pada awalnya kami ingin menganalisa DDD (define daily dose) antara sebelum dan sesudah diterbitkan panduan umum penggunaan antibiotika secara empiris, namun telusur data medis tidak ditemukan data lengkap dosis penggunaan antibiotika pada pasien yang mendapatkan antibiotika di bangsal Kenanga pada kurun waktu Maret - Mei 2016 sehingga pre dan post analisis tidak dapat dikerjakan. Namun telusur ini memberikan informasi bahwa sebelum ini pencatatan pemakaian antibiotika belum sesuai dengan acuan yang ada.Pada laporan ini, dapat dilaporkan DDD per antibiotika selama bulan Juni, Juli dan Agustus.Belum terlihat adanya perubahan pola pemakaian antibiotika pada kurun waktu tersebut.Dibutuhkan observasi lebih lama untuk melihat perubahan sikap para klinisi.Berild dkk.menemukan perubahan pola yaitu penurunan pemakaian antibiotika setelah 2 tahun penerapan panduan pemakaian antibiotika ${ }^{8}$.

Kualitas penggunaan antibiotika harus dievaluasi secara berkala. Alur Gyssens merupakan salah satu cara menganalisa kualitas penggunaan antibiotika yang terukur. Didapatkan data bahwa penggunaan antibiotika yang rasional (Gyssens 0 ) mencapai 46\%, sementara Gyssens V masih dijumpai yaitu sebesar 19\%. Hasil ini masih lebih baikdibandingkan dengan penelitian Luciana di ICU RSFatmawati dimana penggunaan antibiotika tanpa indikasi mencapai 48\%. ${ }^{11}$ Begitu juga dengan penelitian rasionalitas penggunaan antibiotika di RS Sutomo juga menunjukkan bahwa penggunaan antibiotika yang rasional mencapai $27 \% .{ }^{12}$ Penelitian ini seyogyanya dilanjutkan dengan observasi yang lebih lama untuk lebih tahu bagaimana gambaran rasionalitas peresepan antibiotika di Ruang Kenanga ini dan perlu dikembangkan observasi di ruang lain yang mengindikasikan tingginya pemakaian antibiotika.

Pada penelitian ini belum dieksplorasi lebih lanjut bagaimana hubungan dan analisa antara peresepan dengan hasil kultur. Namun didapatkan data 70 pasien yang dilakukan kultur sebelum terapi empiris diberikan. Artinya kultur sudah dilakukan lebih dari 50\% pasien sebelum antibiotika diberikan. Seperti kita ketahui bahwa pilar pemberian antibiotika yang bijak adalah terapi definitif berdasarkan hasil kultur. Sisi positif lainnya adalah RS memiliki lebih banyak data mengenai hasil kultur untuk data dasar penyusunan pola kuman pada semester mendatang. Menurut Standard Operational Procedure (SPO) yang diterbitkan oleh tim PPRA bahwa pengambilan spesimen kultur dilakukan sebelum diberikan antibiotika empiris. Dari beberapa spesimen yang dilakukan kultur dan sensitivitas ternyata hasil kultur positif didapatkan pada spesimen sputum yang mencapai $100 \%$ tumbuh dan yang paling rendah pada spesimen darah yang hanya mencapai $64 \%$.

\section{KESIMPULAN}

Dari penelitian ini dapat disimpulkan bahwa implementasi pedoman penggunaan antibiotika di salah satu bangsal RSUD memberi dampak 
penghitungan DDD kelas antibiotika, dapat dianalisanya rasionalitas peresepan antibiotika pada pasien, meningkatnya kepatuhan untuk melakukan pemeriksaan kultur dan sensitivitas untuk menentukan terapi definitif sehingga dalam jangka panjang dapat menurunkan angka resistensi antibiotika.

\section{DAFTAR PUSTAKA}

1. Centers for Disease Control and Prevention, Office of Infectious Disease. Antibiotic resistance threats in the United States, 2013.

2. Golkar Z, Bagazra O, Pace DG. Bacteriophage therapy: a potential solution for the antibiotic resistance crisis. J Infect Dev Ctries. 2014;13;8(2):129-136.

3. Menteri Kesehatan Republik Indonesia. Peraturan Menteri Kesehatan Nomor: 2406/ MENKES/PER/XII/2011 Tentang Pedoman Umum Penggunaan Antibiotik. Jakarta: Departemen Kesehatan. 2011.

4. Hanberger H, Skoog G, Ternhag A, Giske CG. Antibiotic consumption and antibiotic stewardship in Swedish hospitals. (Online) 2014: 119 (2): 154-161.

5. Negara KS. Analisis implementasi kebijakan penggunaan antibiotika rasional untuk mencegah resistensi antibiotika di RSUP Sanglah Denpasar: studi kasus infeksi Methicillin Resistant Staphylococcus Aureus. Jurnal ARSI. 2014; 1 (1): 42-50.

6. Fauzia D. Strategi optimasi penggunaan antibiotik. Jurnal Ilmu Kedokteran. 2015: 9 (2): 55-64.

7. Hapsari MM, Farida H, Keuter M, dkk. Penurunan penggunaan sntibiotik pada pasien anak. Sari Pediatri, 2006; 8 (1): 16-24.

8. Berild D, Ringertz SH, Lelek M, Fosse B. Antibotic guidelines lead to reductions in the use and cost of antibiotics in a university hospital. (Online) 2009; 33(1): 63-67.

9. Yuniar I dkk. Evaluasi penggunaan antibiotika dengan kartu monitoring antibiotika Gyssens. Sari Pediatri, 2013; 14 (6): 384-90.

10.Ventola CL. The antibiotic resistance crisis. causes and threats. P\&T. 2015;40(4): 277-83.

11.Luciana et al. Rationale antimicrobial use in an intensive care unit in Jakarta, Indonesia: A hospital-based, cross sectional study. Tropical journal of pharmaceutical research. 2015; 14(4):707-14.

12.Trisnadewi IGA, Widodo ADW.Analysis of antibiotic usage in patients with bacteremia in the ICU unit of Dr Soetomo hospital Surabaya. Folia Medica Indonesia. 2014; 50(4): 254-261. 